UDK 311.17:[332.13:338.45]:005.591.3(477)

JEL Classification: L60, 012, R11

Doi: 10.31767/su. 1(84)2019.01.09

S. O. Ishchuk,

DSc in Economics, Professor,

Head of the Department of problems of real sector of regions economy,

SI "Institute of Regional Research named after M. I. Dolishniy

of the NAS of Ukraine",

E-mail: iso.ird@ukr.net

ResearcherID: G-6417-2019,

ORCID: https://orcid.org/0000-0002-3698-9039

\title{
Core Trends in the Development of the Industrial Sector in the Ukrainian Regions
}

The deepening of the processes of European integration updated the need for Ukraine to increase the competitiveness of products of domestic producers to the level of the EU member states. The solution to this problem is impossible without structural modernization of Ukrainian industry. In its turn, the choice of directions and mechanisms for the practical implementation of the new state industrial policy in Ukraine (in particular, at the regional level) should be based on the results of relevant analytical assessments.

The purpose of the article is to determine the key trends in the development of industry in Ukraine based on the evaluation of the dynamics of the values of indicators that systematically characterize the level of functioning of the industrial sector of the national economy in a regional context.

The results of the analysis revealed that industry remains the leading type of economic activity in Ukraine with a share of $34.1 \%$ in the volume of sales of products (goods and services) in 2017. That year the industrial sector of the national economy significantly increased production, export and investment activity, and also reached a higher level of efficiency, in particular, resource (return on assets and labor productivity) and economic (operating profitability, profitability and return on assets). At the same time, there was a further decrease in the level of capital and innovation activity of the industry. To a certain extent, this is due to a slowdown in the dynamics of investment processes - the growth rate of capital investment in industry decreased by $18.4 \mathrm{pp}$.

In order to counteract the established negative trends in industrial development (first of all, deterioration of the structure of assets and decrease of innovation activity, in particular, reduction of the share of innovative products in the total volume of industrial products sold, etc.), as well as for the further growth of profitability of the subjects of industrial activity and increase of the share of industry in commodity exports, the implementation of a complex of organizational and economic and financial mechanisms in the following areas: stimulating the level of innovation activity; activation of attraction of direct foreign investments; increasing export potential.

Key words: industry, production, export, assets, investments, innovation, efficiency, development.

Problem setting. The industrial sector of the national economy lays the solid financial grounds for socio-economic growth in Ukrainian regions. In 2017, the shares of industry, trade and agriculture in the domestic GDP (by production method and in reported prices) were $21.7 \%, 14.1 \%$, and $10.2 \%$, respectively [1]. The industry had the largest employment: 2440.6 thousand persons or $15.1 \%$ of total employment (against 2182.3 thousand in trade and 658.8 thousand in agricultural sector, or $13.5 \%$ and $4.1 \%$ respectively). [2]. The share of large tax payers in this economic sector in the total tax revenues to the public budget was higher than $40 \%$. The industry is the principal part (with the share of $60 \%$ ) in the value added chain of the Ukrainian exports.

However, in spite of possessing large industrial capabilities along with the transit, natural, resource and human capital, Ukraine had 30-fold lower

(C) S. O. Ishchuk, 2019 industrial output and nearly 44-fold lower gross value added than Germany, the EU leader (according to the author's calculations made on Eurostat data [3]). The domestic industry specialization is typical for countries with the commodity-based model of economy, resulting in the poor competitiveness by technological level: the share of high tech industries in the total industrial output in Ukraine is 1.8 times less than in a country like Poland, and their share in the exports is even lower (3.2 times less).

The intensifying Eurointegration processes have emphasized the need to enhance the competitiveness of Ukrainian manufacturers to the level EU member countries. This objective cannot be achieved without structural modernization of the Ukrainian industry. The choice of directions and mechanisms for practical implementation of the new industrial policy of Ukraine (at regional level in particular) has to be based on the results of respective analytical assessments. 
Materials and methods. Given the central role of the industry in the socio-economic development in Ukraine and in gaining competitive positions on global commodity markets, comprehensive studies of this economic sector have been performed by outstanding domestic researchers, first of all by representatives of the National Academy of Sciences (NAS) of Ukraine. Scenarios and future areas of the industry development in Ukraine in view of economic, social and ecological safety are outlined by the research team from the Institute of Industry Economics of the NAS of Ukraine [4]. Issues of financial, monetary, budget and tax support for neoindustrial development and its ecological regulation in Ukraine are highlighted in [5]. Modern tendencies in the development of production systems in the era of Industry 4.0, with focus on the European platform for smart specialization of the industry, are analyzed in [6]. Researchers from the Institute for Economics and Forecasting of the NAS of Ukraine have made in-depth studies of the dynamics, tendencies and perspectives of the domestic exports in the conditions of the free trade zone between Ukraine and EU [7]. But the regional dimension of the industry economics in Ukraine still requires detailed assessments.

The purpose of the article is to determine the key trends in the development of industry in Ukraine based on the evaluation of the dynamics of indicators that systematically characterize the national industry performance in the regional context.

It should be noted that the population of Ukrainian regions does not include the city of Kyiv, because the parameters, studied below, are extremely high for it, which causes essential variations with respective indicators for the rest of regions.

Results of the study. In spite of the slowing rates of the industry development in Ukraine due to the impact of many factors (socio-political, monetary etc.), the industry still remains the core type of economic activities. The share of industrial output in the total sales of goods and services in 2016 reached $34.6 \%$, against $32.5 \%$ in 2012 , but in 2017 it fell by 0.5 percentage points (p. p.) (see Table 1, the author's calculations by use of data from [8;9] and Chief Statistics Departments in Ukrainian regions). This share grew only in seven regions (against 15 in 2016), with the highest growth recorded in Donetsk (by 6.2 p. p.), Ivano-Frankivsk (by 6.2 p. p.) and Poltava (6.0 p. p.) regions.

Our analysis of the Ukrainian regions by industrialization level is based on the share of industrial products in the total sales of goods and services. The top five regions which economy has the highest level of industrialization were Donetsk, Zaporizhzhia, IvanoFrankivsk, Poltava and Sumy regions, with the shares larger than $60 \%$. The cumulated share of these regions in the total sales of industrial products was $34.23 \%$ in 2016, of which $12.47 \%$ accounted for by Donetsk region, $9.04 \%$ and $8.72 \%$ - for Poltava and Zaporizhzhia regions. Since 2014 and on, the largest share $(\approx 20 \%)$ in the total has been in Dnipropetrovsk region.

The index of industrial output in Ukraine grew essentially in 2016 (to reach $2.8 \%$, after the negative dynamics in 2012-2015), but fell in 2017 by 2.4 p. p. (see Figure 1, the author's calculations by data from $[8 ; 10 ; 11])$. At the same time, the rate of growth in the total sales of industrial products was higher by 0.2 p. p. in 2017 (after 3.2 p. p. decrease in 2016). However, the core reason for its increase was the increased index of producer prices in the industry. That is, the production activity in the Ukrainian industry (in value terms) was going up in 2015-2017 on account the heavy inflationary pressure.

The rates of growth in the total sales of industrial products were up in 2017 in 12 regions,

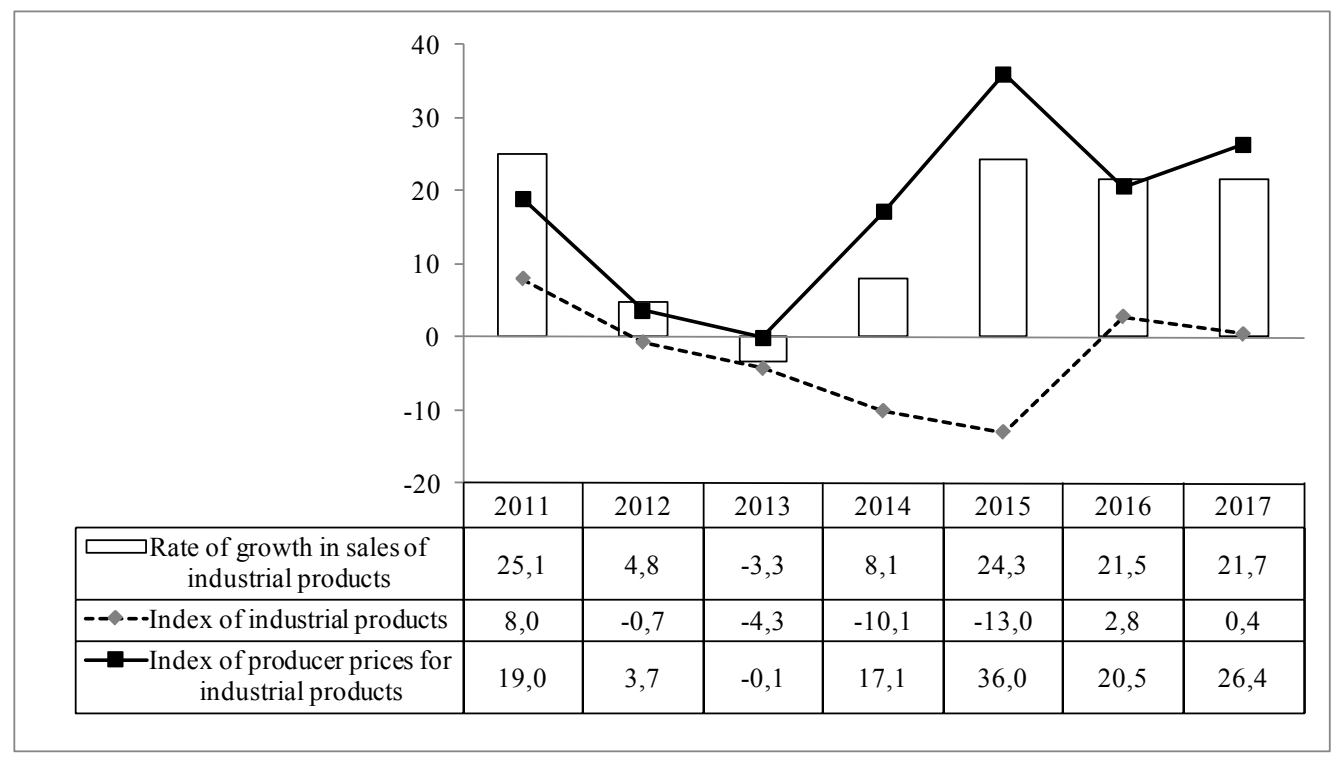

Fig. 1. The dynamics of industrial production indicators in Ukraine, \% 


\begin{tabular}{|c|c|c|c|c|c|c|c|c|c|c|c|c|c|c|}
\hline \multirow{2}{*}{ Region } & \multicolumn{7}{|c|}{$\begin{array}{l}\text { The share of industrial products in the } \\
\text { total sales of goods and services }\end{array}$} & \multicolumn{7}{|c|}{$\begin{array}{l}\text { The rate of growth in the total sales of industrial } \\
\text { products }\end{array}$} \\
\hline & 2011 & 2012 & 2013 & 2014 & 2015 & 2016 & 2017 & 2011 & 2012 & 2013 & 2014 & 2015 & 2016 & 2017 \\
\hline Jkraine & 32.7 & 32.5 & 32.7 & 4.3 & 34.4 & 4.6 & 34.1 & 25.1 & 4.8 & -3.3 & 8.0 & 4.3 & 21.5 & 21.7 \\
\hline & .1 & 48.8 & 54.6 & 6.2 & 42.5 & 4.4 & 43.5 & & & 3.2 & & 7.8 & 24.5 & 19.3 \\
\hline Volyn & .8 & 21.6 & 19.4 & 22.3 & 3.2 & & 19.3 & & & & & & 0.3 & 25.0 \\
\hline Dnipr & 43.5 & 49 & 49.0 & 53 & 51.8 & 51.4 & 49.1 & & 9.9 & -1.3 & & 20.0 & 14.2 & 27.2 \\
\hline$\overline{\text { Don }}$ & 9.0 & 36 & 38.3 & 47 & 5 & 60 & 67.1 & & -9.4 & -8.9 & & 7.7 & 9.1 & 28.2 \\
\hline & .8 & & 51.8 & & & & 41.9 & & & .4 & & & & 10.3 \\
\hline Zaka & 33.6 & 36.2 & 33.4 & 32.0 & 34.4 & 45 & 45.0 & & 12.3 & 0.8 & & 24.4 & 33.2 & 21.3 \\
\hline Zaporizhzhi & 5.6 & 66.4 & 69.4 & 70.8 & & 70.3 & 66.3 & & & -4.4 & & 33.7 & 8 & 21.9 \\
\hline & 69.9 & 65.9 & 53.1 & 59.2 & 64.5 & 55.2 & 61.4 & 74.8 & 4.5 & 129 & 14.2 & 38.2 & 7.3 & 31.0 \\
\hline Kyiv & 24.8 & & 28.3 & 26.1 & & & 27.6 & & & & & & 22.7 & 10.0 \\
\hline Kirove & 36.5 & 35.2 & 39.8 & 36.0 & 35.8 & 34.1 & 35.2 & 22.4 & 29.6 & 17.0 & & 12.9 & 9.5 & 1.1 \\
\hline Luhan & 6.8 & 72 & 69.7 & 73 & 73.9 & 60 & 58.4 & 32.2 & -13.6 & -14.0 & -53.8 & -28.9 & 35.9 & -29.9 \\
\hline Lviv & 6.5 & 26 & 26.4 & 26 & 32.6 & 35. & 34.9 & 2 & & -0.7 & & 47.8 & 23.7 & 26.3 \\
\hline Mykola & 44.7 & 45.8 & 41.8 & 40.3 & 36.1 & 38.6 & 40.3 & 17.7 & 9.9 & -6.3 & & 35.8 & 32.6 & 15.7 \\
\hline Odesa & 19.9 & 20 & 20.3 & 21. & 25.3 & 21 & 20.6 & -12.3 & 4.0 & -2.5 & & 58.9 & 9.9 & 14.5 \\
\hline Poltav & 66.4 & & 64.3 & 65 & & 68 & 74.5 & 2 & 10 & -11.3 & & 28.4 & 29.5 & 34.0 \\
\hline Rivne & 60.5 & 47 & 55.1 & 50.8 & 63.0 & 63.2 & 60.8 & 22.5 & -19.7 & 28.6 & & 40.2 & 16.0 & 17.6 \\
\hline Sumy & 71.2 & 67.9 & 69.4 & 66.4 & 61.0 & 51.5 & 49.6 & & 6.2 & -4.0 & & 38.0 & -1.7 & 18.7 \\
\hline Terno & & & 16.2 & 15.5 & & 35.6 & 36.3 & & -4.6 & 5.0 & & 43 & 21.7 & 31.5 \\
\hline Kharl & 37.8 & 43 & 48.2 & 39.7 & 47.5 & 56.3 & 55.9 & .5 & 22.0 & 0.9 & 1.2 & 64.3 & 34.5 & 20.2 \\
\hline Kherson & 39.6 & 38.0 & 40.3 & 37.8 & 38.0 & 46.3 & 43.0 & 14.7 & -7.0 & 6.6 & 11.3 & 42.9 & 48.6 & 9.3 \\
\hline Khme & 52.5 & 50.5 & 50.3 & 37.9 & 34.8 & 36.7 & 35.5 & 27.4 & 10.5 & 5.6 & -8.6 & 25.0 & 22.0 & 29.8 \\
\hline Cherka & 52.3 & 50.8 & 50.9 & 51.3 & 46.2 & 49.5 & 47.9 & 20.9 & 12.3 & -5.1 & 23.2 & 27.9 & 20.4 & 17.8 \\
\hline Chernivtsi & 32.2 & 30.9 & 32.7 & 32.5 & 37.7 & 45.6 & 38.6 & 27.4 & 1.0 & -0.2 & 14.1 & 45.9 & 38.1 & 10.7 \\
\hline Chernihiv & 56.4 & 58.3 & 56.2 & 53.8 & 46.4 & 50.6 & 49.4 & 25.5 & 27.2 & -3.2 & 16.7 & 28.1 & 37.8 & 22.5 \\
\hline
\end{tabular}

with the highest ones recorded in Ivano-Frankivsk (23.7 p. p.), Donetsk (19.1 p. p.), Sumy (18.7 p. p.) and Dnipropetrovsk (13.0 p. p.) regions (see Table 1). Due to the intensive growth in the production activity in Donetsk region in 2017, this region could approach, by $99.68 \%$, the level of 2011 by the total sales of industrial products. However, in Luhansk region, the essential increase in the rates of growth of the total sales of industrial products (up to $35.9 \%$ ) was reversed in 2017 , when the production activity fell down below the level of 2015. As a result, the total sales of industrial products in this region made only $23.26 \%$ of 2011 .

A negative tendency in the domestic industry is its weakening export positions. The share of industrial goods in the total exports of goods and services from Ukraine fell by 16.2 p. p. in 2011-2016 (see Table 2, the author's calculations by use of data from [8; 12] and Chief Statistics Departments in Ukrainian regions). It so happened because this share decreased in 15 regions of Ukraine.

In 2017, the share of industrial goods in the total exports of goods and services from Ukraine grew by
1.8 p. p. and reached $61.3 \%$, against $75.7 \%$ in 2011 . The growth was recorded in 11 regions, especially in Ivano-Frankivsk (by 20.9 p. p.) and Chernihiv (by 17.7 p. p.) regions. Industrial products used to prevail in the export structure in Dnipropetrovsk, Donetsk, Zakarpattia, Zaporizhzhia, Luhansk, and Poltava regions, where their shares reached $80 \%$. But in Kyiv, Mykolaiv, Odesa, Khmelnytskyi, and Chernihiv regions, the share of industrial goods in the total exports was smaller than $50 \%$.

The rates of growth in the exports of industrial products from Ukraine fell down in 2012-2016 to below zero level, but rapidly grew in 2017 , to reach $19.82 \%$. The rates were up in all the regions (except for Kyiv, Kirovohrad, and Luhansk regions), with the most essential growth recorded in Cherkasy region (1.46 times). The intensified export activity of the domestic industry in 2017 increased the share of exports in the total sales of industrial products by 0.8 p. p. This share was up in 14 regions; its average for Ukraine was $33.4 \%$, against $37.8 \%$ in 2011 . The export activity of the industry in 2017 grew to the highest extent in Ivano-Frankivsk region. As a result, the 


\begin{tabular}{|c|c|c|c|c|c|c|c|c|c|c|c|c|c|c|}
\hline \multirow[t]{2}{*}{ Region } & \multicolumn{7}{|c|}{$\begin{array}{l}\text { The share of industrial goods in the total } \\
\text { exports of goods and services }\end{array}$} & \multicolumn{7}{|c|}{$\begin{array}{c}\text { The share of exports in the total sales of } \\
\text { industrial products }\end{array}$} \\
\hline & 2011 & 2012 & 2013 & 2014 & 2015 & 2016 & 2017 & 2011 & 2012 & \begin{tabular}{|l|}
2013 \\
\end{tabular} & 2014 & 2015 & 2016 & 2017 \\
\hline Ukraine & 75.7 & 69.2 & 66.8 & 67.0 & 60.9 & 59.5 & 61.3 & \begin{tabular}{|l|}
37.8 \\
\end{tabular} & 34.2 & \begin{tabular}{|l|}
32.2 \\
\end{tabular} & 36.7 & \begin{tabular}{|l|}
36.1 \\
\end{tabular} & 32.6 & 33.4 \\
\hline Vinnytsia & 3.2 & 77.2 & 75.0 & 66.8 & 66.9 & 72.9 & 68.6 & 22.1 & 19.1 & 17.3 & 20.8 & 31.3 & 37.0 & 37.5 \\
\hline Volyn & 0.4 & 83.0 & 75.2 & 79.1 & 79.4 & 79.9 & 77.0 & 41.5 & 37.7 & 37.8 & 51.2 & 61.0 & 57.8 & 52.7 \\
\hline Dnipropetrovsk & 5.0 & 94.9 & 93.3 & 94.5 & 93.8 & 95.0 & 96.3 & 40.6 & 36.2 & 35.4 & 40.7 & 45.3 & 42.4 & 41.8 \\
\hline Donetsk & 6.0 & 93.8 & 94.4 & 93.5 & 89.4 & 86.7 & 93.7 & 50.9 & 45.8 & 44.6 & 55.7 & 41.7 & 41.3 & 42.6 \\
\hline Zhytomyr & 0.7 & 87.3 & 85.5 & 77.3 & 79.3 & 74.1 & 72.3 & 26.7 & 24.7 & 26.9 & 35.4 & 31.9 & 29.5 & 33.3 \\
\hline Zakarpattia & 94.7 & 94.8 & 80.9 & 86.6 & 83.1 & 84.4 & 82.0 & 44.5 & 40.8 & 47.8 & 54.0 & 51.3 & 52.8 & 54.7 \\
\hline Zaporiz & 2.8 & 91.5 & 92.3 & 91.1 & 88.3 & 85.8 & 86.6 & 35.6 & 37.9 & 36.5 & 43.5 & 45.3 & 35.3 & 38.7 \\
\hline Ivano-Fran & 7.7 & 88.2 & 74.1 & 71.6 & 71.2 & 53.7 & 74.6 & 29.7 & 24.5 & 14.5 & 18.7 & 18.7 & 23.1 & 29.3 \\
\hline Kyiv & 68.2 & 62.2 & 58.6 & 58.7 & 55.2 & 52.0 & 49.3 & 25.8 & 21.2 & 17.5 & 23.1 & 27.5 & 24.7 & 23.1 \\
\hline Kirovohrad & 82.9 & 85.6 & 90.2 & 86.1 & 71.8 & 69.0 & 67.4 & 25.2 & 28.2 & 43.9 & 42.8 & 29.6 & 31.8 & 26.6 \\
\hline Luhansk & 4.7 & 95.5 & 95.0 & 92.9 & 91.9 & 96.1 & 84.6 & 53.0 & 39.5 & 38.7 & 67.1 & 22.9 & 31.3 & 25.9 \\
\hline Lviv & 85.7 & 82.4 & 73.1 & 70.2 & 66.5 & 67.6 & 68.5 & 28.7 & 29.5 & 28.5 & 36.2 & 39.1 & 39.9 & 40.8 \\
\hline Mykolaiv & 59.5 & 50.2 & 38.9 & 38.7 & 36.7 & 33.1 & 34.8 & 40.3 & 43.2 & 38.4 & 41.3 & 47.0 & 38.2 & 40.7 \\
\hline Odesa & 6.1 & 50.8 & 42.7 & 40.6 & 39.2 & 33.9 & 37.7 & 36.4 & 42.9 & 34.5 & 40.0 & 41.9 & 33.9 & 38.3 \\
\hline Poltava & 83.9 & 92.8 & 91.6 & 85.3 & 82.7 & 81.8 & 80.4 & 31.2 & 31.7 & 28.0 & 25.9 & 24.9 & 21.3 & 21.0 \\
\hline Rivne & 80.3 & 80.2 & 79.3 & 79.2 & 81.2 & 76.1 & 69.6 & 26.9 & 30.2 & 22.1 & 25.7 & 26.4 & 21.7 & 21.2 \\
\hline Sumy & 92.5 & 90.1 & 88.6 & 81.2 & 76.3 & 79.1 & 66.2 & 33.3 & 34.1 & 28.9 & 28.3 & 29.2 & 31.7 & 28.7 \\
\hline Ternopil & 86.0 & 70.4 & 61.4 & 57.0 & 57.2 & 57.0 & 59.3 & 21.1 & 18.2 & 25.6 & 29.8 & 30.8 & 33.1 & 31.8 \\
\hline Kharkiv & 76.4 & 74.9 & 72.5 & 74.1 & 67.7 & 67.1 & 63.9 & 20.6 & 18.1 & 17.3 & 26.9 & 20.4 & 14.4 & 13.9 \\
\hline & 58.5 & 57.3 & 61.3 & 46.9 & 52.4 & 49.2 & 52.8 & 16.1 & 16.4 & 18.5 & 18.3 & 17.5 & 13.6 & 16.0 \\
\hline Khmelnytskyi & 66.7 & 65.5 & 68.5 & 58.0 & 46.3 & 54.3 & 49.0 & 15.1 & 15.8 & 16.5 & 22.9 & 21.4 & 19.2 & 20.3 \\
\hline Cherkasy & 78.5 & 76.6 & 72.9 & 64.2 & 60.6 & 57.6 & 64.3 & 23.3 & 19.5 & 15.1 & 13.0 & 12.4 & 12.5 & 16.1 \\
\hline Chernivtsi & 90.4 & 87.9 & 85.9 & 72.8 & 66.0 & 72.7 & 66.6 & 25.4 & 23.0 & 23.8 & 26.7 & 27.2 & 27.5 & 29.7 \\
\hline Chernihiv & 65.6 & 64.0 & 63.9 & 58.1 & 45.7 & 30.9 & 48.6 & 21.3 & 14.5 & 15.7 & 22.7 & 20.2 & 17.7 & 17.8 \\
\hline
\end{tabular}

share of this region in the total exports of industrial goods from Ukraine grew by 0.49 p. p. Also, a growth was recorded in Lviv (0.18 p. p.), Odesa (0.13 p. p.) and Cherkasy ( 0.27 p. p.) regions. However, the export capacities of the domestic industry are determined by Dnipropetrovsk, Donetsk, and Zaporizhzhia regions, which cumulated share in the industry exports is higher than $50 \%$. The respective shares of each of these three regions in the total exports of industrial goods in 2017 made $25.37 \%, 15.68 \%$, and $10.03 \%$ (against 18.64\%, 31.18\%, and 6.64\% in 2011).

2015-2016 marked the recovery of capitalizationrelated activities at industrial enterprises: the rate of growth in non-current assets increased by 6.9 p. p. relative to 2014 (Table 3, the author's calculations by data from [13] and Chief Statistics Departments in Ukrainian regions). But this rate decreased again in 2017 (by 3.4 p. p. in average), being negative in four regions: Dnipropetrovsk, Donetsk, Luhansk, and Mykolaiv; in the latter two regions the strongest decrease was recorded.

At the same time, in spite of the rapidly falling rates of growth in non-current assets (from 15.2\% in 2011 to $-5.6 \%$ in 2017 ), industrial entities located in
Donetsk, Dnipropetrovsk, and Kyiv region had the largest production capacities among the Ukrainian regions. The cumulated share of the three regions in the structure of non-current assets of the domestic industry was nearly $50 \%$.

The share of non-current assets in the total industrial assets in Ukraine, which decreased by 11.9 p. p. in 2014-2017, has continued to go down. In 2017, it decreased in 13 regions (against 21 regions in 2016), with the strongest decrease (24.9 p. p.) recorded in Mykolaiv region. The decreasing capital activity worsened the structure of industrial assets in Ukrainian regions. In 2017, non-current assets dominated in the structure of industrial assets only in two regions (Zakarpattia and Kyiv): their share, higher than 50\%, met the recommended level, whereas in 2013 such regions numbered 14.

In fact, the negative dynamics of non-current assets shows that the Ukrainian industry has lost its production capacities. For comparison, in Poland the share of non-current assets in the industrial assets continued to be higher than $60 \%$ and had upward tendency: from $61.1 \%$ in 2011 to $63.8 \%$ in 2017 (the author's calculations by use of data from 
Indicators of capital in the industry, by Ukrainian region

$(\%)$

\begin{tabular}{|c|c|c|c|c|c|c|c|c|c|c|c|c|c|c|}
\hline \multirow{2}{*}{ Region } & \multicolumn{7}{|c|}{ The rate of growth in non-current assets } & \multicolumn{7}{|c|}{$\begin{array}{l}\text { The share of non-current assets in the total } \\
\text { assets }\end{array}$} \\
\hline & 2011 & 2012 & \begin{tabular}{|l|l}
2013 \\
\end{tabular} & 2014 & 2015 & 2016 & 2017 & 2011 & 2012 & 2013 & 2014 & 2015 & 2016 & 2017 \\
\hline Ukraine & 13.0 & 45.2 & 7.9 & 3.4 & 8.1 & 10.3 & 6.9 & 47.6 & 54.5 & 55.2 & 53.1 & 49.0 & 45.6 & \\
\hline Vinnytsia & 4.1 & 41.4 & 20.8 & 11.2 & & 12.6 & 19.5 & 46.1 & 50.8 & 1.3 & 56.1 & 52.3 & 7.2 & 2.0 \\
\hline Volyn & 2.2 & 7.9 & 3.1 & 5.5 & 32.2 & 5.2 & 17.1 & 50.7 & 53.0 & 53.6 & 51.2 & 49.4 & 44.5 & 42.5 \\
\hline Dnipropet & 1.4 & 2.0 & -1.4 & 41.4 & 0.1 & 9.9 & -4.1 & 53.1 & 54.1 & 52.5 & 55.0 & 49.7 & 6.0 & 7.5 \\
\hline & 15.2 & 10.8 & 7.5 & & & -1.5 & -5.6 & & 48.4 & 49.0 & 49.9 & & 2.2 & 7.7 \\
\hline Zhytomyr & 6.6 & 20.9 & 5.8 & 10.0 & -1.8 & 27.3 & 7.1 & 56.3 & 58.9 & 57.6 & 55.7 & 52.1 & 50.4 & 48.4 \\
\hline Zakarpattia & 6.8 & 26.1 & 8.6 & 15.2 & 24.1 & 16.0 & 5.9 & 49.6 & 53.2 & 57.9 & 56.9 & 55.4 & 53.8 & 51.2 \\
\hline & .7 & 25. & 4.5 & 24.8 & 17.8 & 3.0 & 15.2 & 50.6 & 55.1 & 4.9 & 53.7 & 52.1 & 4.0 & 40.6 \\
\hline Ivano- & 26.4 & 25.5 & 21.8 & 20.6 & -17.3 & -1.9 & 23.1 & 54.2 & 65.2 & 61.9 & 59.4 & 35.6 & 31.3 & 32.7 \\
\hline Kyiv & 8.4 & 21.0 & 31.9 & 13.0 & 12.6 & 18.9 & 14.2 & 51.2 & 51.2 & 55.1 & 54.5 & 52.8 & 53.2 & 60.9 \\
\hline & .7 & 14. & 11.2 & 13.4 & -6.9 & -4.9 & 40.4 & 35.5 & 35.8 & 6.2 & 41.0 & 45.7 & 3.5 & 44.5 \\
\hline Luhansk & & 18.5 & -35.6 & & -15.0 & 2.3 & -17.4 & 46.3 & 46.3 & 43.4 & 43.2 & 36.3 & 29.4 & 28.1 \\
\hline Lviv & 8.2 & 21.5 & 19.3 & 7.2 & 7.4 & 9.7 & 38.6 & 48.7 & 51.3 & 53.7 & 48.1 & 44.7 & 37.4 & 41.0 \\
\hline & & & 21.3 & -4.2 & 249.9 & -5.5 & -60.5 & 44.9 & 41.2 & 45.0 & 43.4 & 63.1 & 60.6 & 35.7 \\
\hline Ode & & 46. & & & 11.9 & 12.3 & \begin{tabular}{|l|}
9.4 \\
\end{tabular} & 53.8 & 62.9 & 62.8 & 50.4 & 52.9 & 9.5 & 47.3 \\
\hline Poltava & 8.7 & 30.6 & 15.8 & 12.1 & 4.7 & 2.2 & 19.3 & 40.4 & 46.4 & 48.5 & 45.8 & 40.4 & 37.5 & 41.3 \\
\hline Rivne & -2.2 & 11.7 & 31.3 & 23.4 & -0.1 & -2.9 & & 42.2 & 39.8 & 39.3 & 44.9 & 37.6 & 36.1 & 43.4 \\
\hline Sumy & 17.6 & 3.6 & 5.4 & -6.3 & 6.9 & 15.1 & 18.4 & 42.5 & 40.2 & 41.1 & 35.4 & 32.2 & 33.9 & 33.4 \\
\hline Ternopil & 0.0 & -11.1 & 38.5 & 13.4 & -37.0 & 19.0 & 24.3 & 50.5 & 48.1 & 57.2 & 58.3 & 42.5 & 34.2 & 37.5 \\
\hline Kharkiv & & 25.4 & 6.0 & 5.1 & 7.0 & 15.9 & 24.3 & 38.8 & 37.0 & 38.9 & 37.1 & 34.5 & 32.7 & 33.9 \\
\hline Kherson & 14.5 & 14.4 & 11.4 & -5.1 & 13.6 & 6.4 & 25.6 & 43.9 & 44.9 & 52.1 & 42.9 & 39.6 & 35.7 & 41.5 \\
\hline Khmelnytskyi & 14.9 & 12.6 & 11.3 & 6.3 & 18.0 & 9.8 & 26.5 & 56.1 & 57.0 & 58.6 & 53.2 & 51.5 & 48.0 & 48.6 \\
\hline Cherkasy & 38.3 & 21.8 & -1.7 & 2.6 & 2.3 & 6.9 & 9.3 & 26.9 & 26.7 & 28.1 & 22.6 & 19.5 & 19.6 & 21.2 \\
\hline & 4.4 & -12.0 & 6.8 & -4.4 & 21.4 & 14.1 & 8.5 & 59.8 & 58.6 & 63.2 & 58.7 & 58.9 & 50.3 & 47.7 \\
\hline Chernihiv & -10.7 & 17.4 & 20.4 & 18.7 & 6.3 & 15.8 & 13.2 & 40.5 & 45.5 & 49.0 & 49.6 & 42.9 & 35.4 & 32.7 \\
\hline
\end{tabular}

the Central Statistical Office of Poland [14]). The decreasing share of non-current assets in the total industrial assets in Ukraine limits the capabilities for its future development. This problem is aggravated by the dominance of resource-intensive and energyintensive technologies, high depreciation of fixed assets $(59.1 \%)$, especially in manufacturing industries (64.6\%), and negative dynamics of investment processes.

Beginning with 2012, the rate of growth in capital investment in the Ukrainian industry was downward, and beginning with 2013 the similar trend occurred in the rate of growth in e foreign direct investment (FDI), which fell below zero level in 2014-2016 (see Table 4, the author's calculations by use of data from $[15 ; 16]$ and Chief Statistics Departments in Ukrainian regions). In 2016, the former indicator grew substantially (by 32.7 p. p. relative to 2015), and approached the level of 2011 (the difference was 7.8 p. p.). But the rate of FDI growth in the industry continued to fall (to $-28.4 \%$ ). As a result, the share of the industry in the total FDI in 2016 decreased by 5.1 p. p.

In 2017, the average rate of growth in capital investment in the Ukrainian industry decreased by 18.4 p. p. (to $15.9 \%$ ). Its decrease was registered in 18 regions, with the strongest one (to below zero level) in Luhansk, Kyiv, and Mykolaiv regions. At the same time, Vinnytsia, Volyn, Dnipropetrovsk, Zaporizhzhia, Kharkiv, and Kherson regions could increase the capital investment in the industry, with the strongest increase (3.7 times) in the latter region. The highest capacities in terms of capital investment in the industry were kept by Dnipropetrovsk, Donetsk, Zaporizhzhia, and Kyiv regions: their respective shares in 2017 were $22.57 \%, 9.14 \%, 9.17 \%$, and $10.58 \%$.

Ukraine could overcome the persisting negative tendency of 2013-2016 in the inflow of FDI to the national economy as a whole and industry in particular. In 2017, the average rate of growth in FDI to the domestic industry reached $11.0 \%$. The rate became positive in 15 regions (against 4 in 2016). 


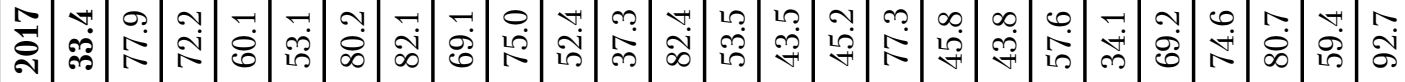

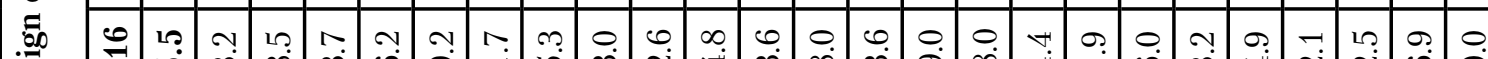
光

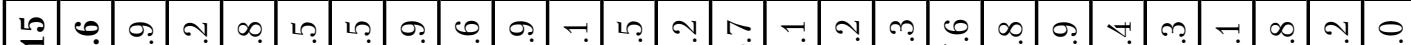

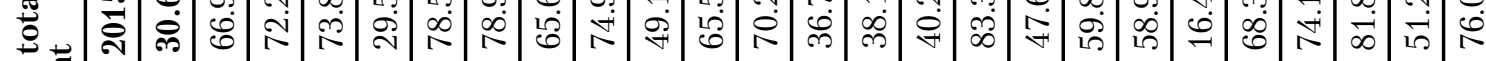

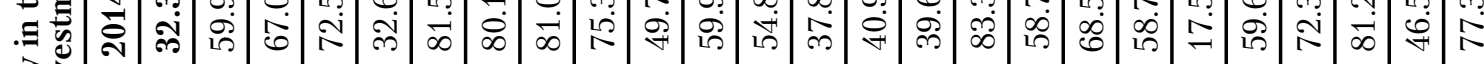

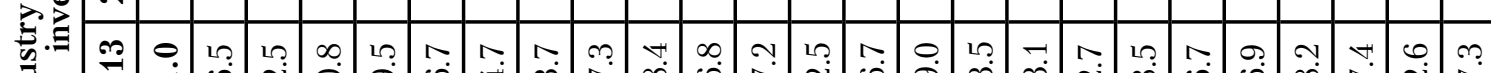

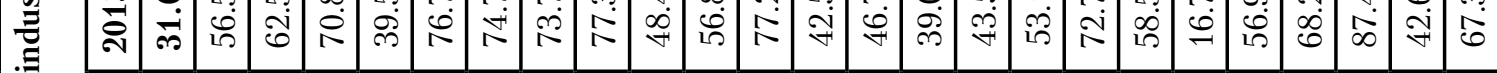

ש゙

尝 宗

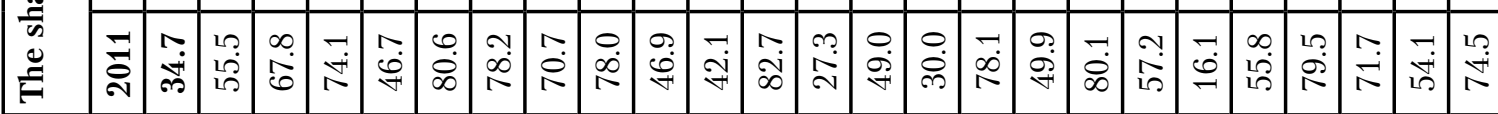

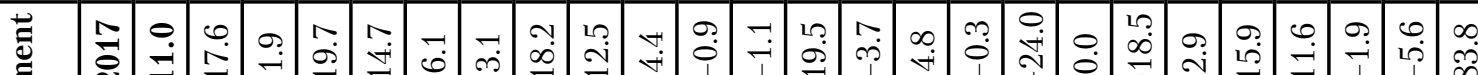

.

•

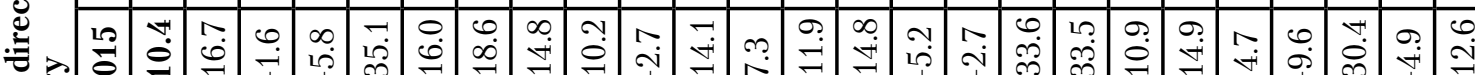

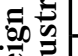

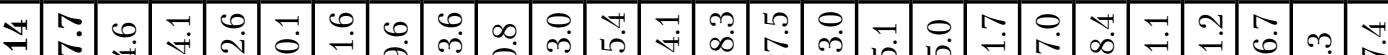

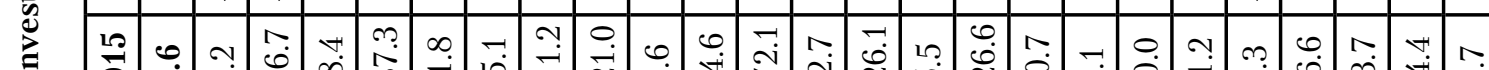
$\because$

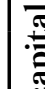


The highest growth in the industrial FDI in 2016 and 2017 was recorded in Chernihiv region: 209.1 i 83.8\% respectively. High rates of growth in FDI (more than $18 \%$ ) were reached in Dnipropetrovsk, Zaporizhzhia, and Lviv regions. Kharkiv region could slightly increase FDI in the industry (by $2.9 \%$ ) its cumulative reduction in $2012-2016$ by $52.1 \%$. This region had the lowest share of industry in the total FDI, which dynamics was nevertheless upward: 34.1\% in 2017 against $16.1 \%$ in 2011.

Due to the intensified inflow of FDI to the domestic industry in 2017, the industry's share in the total FDI in Ukraine grew by 7.9 p. p. This growth was reported by 14 regions; the highest one was in Donetsk (by 16.9 p. p.) and Lviv (by 15.5 p. p.) regions. The highest shares (more than $80 \%$ ) of the industry in the total FDI could be kept in Zhytomyr, Zakarpattia, Luhansk, Cherkasy, and Chernihiv regions. But the largest potentials in terms of attracting FDI to the industry are in Dnipropetrovsk region (leaving the rest of the regions far behind), although its share in the total FDI in the domestic industry decreased by nearly twice in 2016-2017 in relation to the previous period.

To sum up this part of the study, the investment climate in Ukraine could be considerably improved, which is confirmed by the increasing rates of growth in FDI in the domestic industry.

The innovation activity of the domestic industry grew in 2015-2016, but decreased in 2017. The share of enterprises introducing innovation in the total number of industrial enterprises reduced by 2.3 p. p. relative to 2016 , and the share of innovation expenditures in the total capital investment decreased by 13.3 p. p. (see Table 5, the author's calculations by data from $[16 ; 17 ; 18]$ and Chief Statistics Departments in Ukrainian regions). As a result, the share of innovation expenditures became 2.5 p. p. smaller than in crisis-hit 2014. The share of innovative products in the total sales of industrial products was falling year by year in the period under study (the cumulative decrease was 5.43 -fold), and made only $0.7 \%$ in 2017 . Note that this indicator is missing for 2016.

In spite of the shrinking innovation activity across the domestic industry, there were some regions in 2017 that could increase some of the innovationrelated indicators. Thus, the share of enterprises introducing innovations in the total number of industrial enterprises grew in Volyn, Zakarpattia, Ivano-Frankivsk, Ternopil, Kharkiv, and Cherkasy regions. In the latter three regions, the share exceeded 23\% (against 14.3\% across Ukraine).

The share of innovation expenditures in the total capital investment increased in 2017 in 8 regions and became the highest in Kirovohrad (31.1\%) and Sumy (28.1\%) regions. But the share of innovative products in the total sales of industrial products was smaller than $1 \%$ in 14 regions. It was higher than $2 \%$ only in Zaporizhzhia, Sumy, and Kharkiv regions.

The highest innovation activity in the industry (assessed by three analyzed indicators) could be found in 2017 in Zaporizhzhia, Kirovohrad, Sumy, Kharkiv, and Cherkasy regions, the lowest one - in Rivne and Khmelnytskyi regions. The overall innovation activity of the Ukrainian industry was relatively low. In 2017, Ukraine performed 1.3 times worse than Poland by the share of enterprises introducing innovations in the total number of industrial enterprises, and 12.6 times worse by the share of the innovative products in the total sales of industrial products.

The production capacities utilization in the industry is measured by two key indicators: capital productivity and labor productivity, showing the effectiveness of management of fixed and human assets. In the period under study, these indicators had different dynamics (see Table 6, the author's calculations by use of data from $[2 ; 9 ; 13]$ and Chief Statistics Departments in Ukrainian regions). The capital productivity decreased by 1.55 times in 20112013, but grew by 1.5 times in the following four years relative to 2013. The labor productivity showed an upward tendency over the period under study (except for a slight decrease in 2013); in 2017 it exceeded the figure of 2011 by 2.8 times.

The resource efficiency in the Ukrainian industry in 2017 compared with the previous year was dependent on the following factors: the increased sales of industrial products (in value terms, by $21.68 \%$ ); the increased value of non-current assets (by $6.93 \%$ ); the reduced employment across the industry (by $2.17 \%$ ).

The highest per capita labor productivity in the industry could be found in Poltava region: 1.956 million UAH (against 1.451 million $\mathrm{UAH}$ in 2016). This indicator grew in Poltava region as a result of the increased sales of industrial products (by $34.0 \%$ ) in parallel with the reduced average employment in the industry (by $0.6 \%$ ). Also, the industry in Poltava region could reach considerable growth in the capital productivity (by 47.8 p. p.), allowing it to join, once again, the group of top five by this indicator: Poltava, Sumy, Kharkiv, Cherkasy, and Chernihiv regions (higher than $4 \mathrm{UAH}$ / UAH).

One of the remarkably positive tendencies was the slowing rates of employment reduction in the domestic industry. The industrial employment grew in eight regions in 2017 (against seven in 2016 and one in 2015); the largest growth was recorded in Lviv region (6.38\%). But in Luhansk, Donetsk, and Dnipropetrovsk regions the employment reduced by $17.27 \%, 13.78 \%$ and $3.42 \%$. respectively. In spite of this, in the two latter regions (along with Kharkiv region) the share of industrial employment was the highest one: $14.58 \%$ in Dnipropetrovsk region and $8.58 \%$ in Donetsk region. But in Luhansk region this share decreased to $2.91 \%$ (against $8.17 \%$ in 


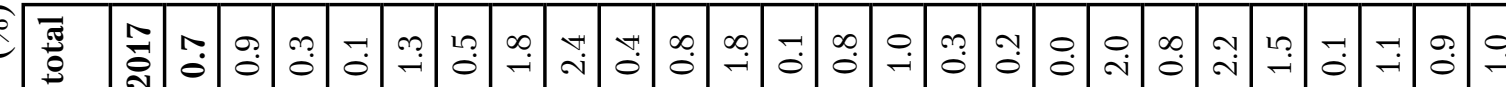
$\Phi$

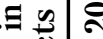

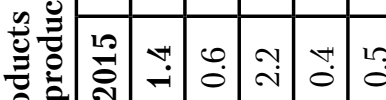

:

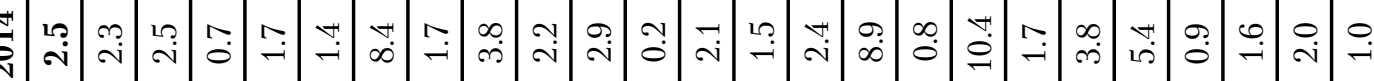

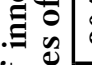

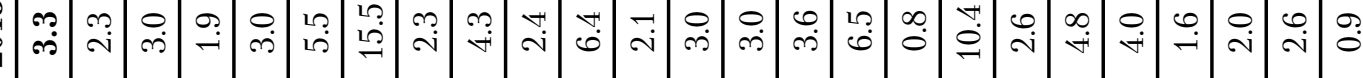

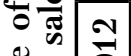

营

Е

$\mathscr{E}$

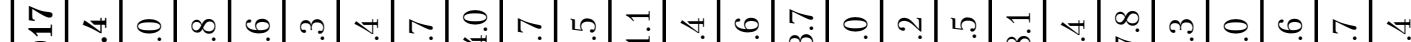

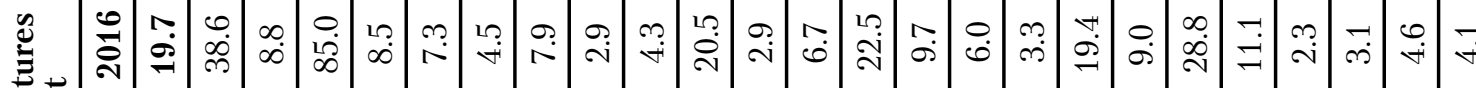

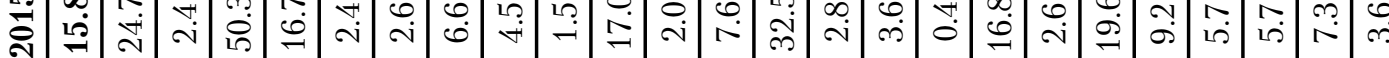

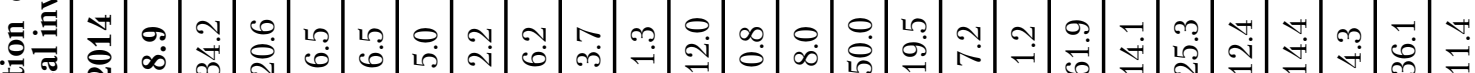


$(\%)$

\begin{tabular}{|c|c|c|c|c|c|c|c|c|c|c|c|c|c|c|}
\hline \multirow{2}{*}{ Region } & \multicolumn{7}{|c|}{ Capital productivity, UAH/UAH } & \multicolumn{7}{|c|}{ Labor productivity, million UAH / person } \\
\hline & 2011 & 2012 & 2013 & 2014 & 2015 & 2016 & 2017 & 2011 & 2012 & 2013 & 2014 & 2015 & 2016 & 2017 \\
\hline Ukraine & 980 & 1.429 & 1.280 & 1.338 & 1.539 & 1.695 & 1.929 & 0.389 & 0.409 & 0.404 & 0.493 & & 0.865 & 1.076 \\
\hline & & & & & & & & 280 & & & & & 43 & \\
\hline Vol & & 1.760 & 648 & & 2.104 & .408 & 2.569 & 196 & 0.206 & & .261 & & 465 & .576 \\
\hline Dni & 471 & 1.585 & 1.587 & 1.300 & 1.559 & 1.620 & 2.148 & 0.488 & & & 0.658 & & 0.977 & 1.288 \\
\hline & & 928 & & & 31 & 73 & 2.0 & 0.516 & & & & & 893 & 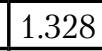 \\
\hline & & 1.638 & & 573 & 2.256 & & 2.388 & 0.183 & & & & & 465 & .509 \\
\hline & 029 & 1.806 & 1.676 & 1.618 & 1.622 & 1.862 & 2.133 & 0.145 & & 66 & 0.187 & .237 & 0.314 & 0.382 \\
\hline & 209 & 1.779 & 1.627 & 616 & 834 & 083 & \begin{tabular}{|l|}
2.204 \\
\end{tabular} & 0.422 & & & 0.566 & & 0.938 & 1.159 \\
\hline & & 1.67 & & 31 & 90 & & 2.2 & 0.338 & & & 0.366 & & 542 & 715 \\
\hline Kyi & 1.248 & 1.283 & 1.1 & 1.0 & 1.137 & & 1.1 & 0.341 & & & 0.518 & & 813 & .903 \\
\hline & 197 & 2.671 & 2.657 & 2.050 & 2.486 & 2.864 & 2.397 & 0.219 & & 0.336 & 0.389 & & 0.517 & 0.605 \\
\hline & 5 & 1.935 & & 1.1 & .930 & 1.2 & 1.0 & \begin{tabular}{|l}
0.388 \\
\end{tabular} & & & 0.195 & & 0.395 & 0.335 \\
\hline $\mathrm{Lv}$ & 767 & 1.566 & \begin{tabular}{|l|}
1.302 \\
\end{tabular} & 1.389 & 1.911 & 2.155 & 1.964 & 0.200 & .219 & 0.219 & 0.257 & 393 & 0.486 & 0.577 \\
\hline & 277 & 2.276 & 1.759 & 2.087 & 0.810 & 1.138 & \begin{tabular}{|l|}
3.334 \\
\end{tabular} & 0.295 & & \begin{tabular}{|l}
0.309 \\
\end{tabular} & 0.375 & & \begin{tabular}{|l}
0.699 \\
\end{tabular} & 0.821 \\
\hline & 0 & 1.18 & & 1.3 & 1.9 & 1.9 & 1.8 & \begin{tabular}{|l}
0.290 \\
\end{tabular} & & & 0.373 & & \begin{tabular}{|l}
0.712 \\
\end{tabular} & \\
\hline & .539 & 3.003 & 2.300 & 2.489 & 3.054 & \begin{tabular}{|l}
3.870 \\
\end{tabular} & 4.348 & 0.587 & 638 & 0.584 & 0.749 & 54 & 1.451 & 1.956 \\
\hline Riv & 2.643 & \begin{tabular}{|l|}
1.901 \\
\end{tabular} & \begin{tabular}{|l}
1.862 \\
\end{tabular} & 1.842 & 2.586 & \begin{tabular}{|l}
3.088 \\
\end{tabular} & 3.445 & 0.231 & 0.186 & \begin{tabular}{|l}
0.242 \\
\end{tabular} & 0.301 & .415 & 0.489 & 0.590 \\
\hline $\mathrm{Sul}$ & 21 & 3.40 & \begin{tabular}{|l|}
3.1 \\
\end{tabular} & 3.681 & 4.7 & 4.0 & 4.0 & 0.274 & & 0.2 & \begin{tabular}{|l|l} 
& 0.349 \\
\end{tabular} & & 0.503 & 0.607 \\
\hline & 874 & 2.010 & 1.524 & 1.563 & 3.559 & 3.640 & 3.853 & \begin{tabular}{|l|l|} 
\\
\end{tabular} & 0.1 & \begin{tabular}{|l}
0.197 \\
\end{tabular} & 0.244 & & 0.470 & 0.604 \\
\hline & 3.372 & 3.280 & \begin{tabular}{|l}
3.123 \\
\end{tabular} & 2.638 & 4.049 & 4.701 & \begin{tabular}{|l}
4.544 \\
\end{tabular} & \begin{tabular}{|l|l|} 
\\
\end{tabular} & \begin{tabular}{|l|l|}
0.309 \\
\end{tabular} & \begin{tabular}{|l|l}
0.315 \\
\end{tabular} & \begin{tabular}{|l}
0.297 \\
\end{tabular} & \begin{tabular}{|l}
0.497 \\
\end{tabular} & \begin{tabular}{|l}
0.678 \\
\end{tabular} & \begin{tabular}{|l|l|} 
\\
\end{tabular} \\
\hline & .209 & \begin{tabular}{|l|l}
1.796 \\
\end{tabular} & \begin{tabular}{|l}
1.719 \\
\end{tabular} & 2.016 & 2.536 & 3.541 & \begin{tabular}{|l|}
3.081 \\
\end{tabular} & 0.240 & 0. & 0.231 & \begin{tabular}{|l|l|} 
\\
\end{tabular} & & 0.646 & 0.714 \\
\hline & 2.072 & \begin{tabular}{|l}
2.032 \\
\end{tabular} & \begin{tabular}{|l}
1.928 \\
\end{tabular} & 1.657 & 1.756 & \begin{tabular}{|l}
1.950 \\
\end{tabular} & \begin{tabular}{|l}
2.000 \\
\end{tabular} & 0.216 & 0.236 & 0.250 & 0.239 & 0.324 & 0.386 & 0.506 \\
\hline & 3.172 & \begin{tabular}{|l}
2.925 \\
\end{tabular} & \begin{tabular}{|l}
2.822 \\
\end{tabular} & 3.390 & 4.236 & 4.775 & \begin{tabular}{|l}
5.146 \\
\end{tabular} & 0.353 & 0.396 & \begin{tabular}{|l|l}
0.378 \\
\end{tabular} & 0.494 & 0.640 & 0.788 & 0.933 \\
\hline & 1.403 & 1.610 & 1.504 & 1.794 & 2.157 & 2.611 & 2.665 & 0.110 & 0.103 & \begin{tabular}{|l|l|}
0.104 \\
\end{tabular} & \begin{tabular}{|l|l} 
& 0.128 \\
\end{tabular} & 0.189 & 0.255 & 0.272 \\
\hline Chernihiv & 3.992 & 4.323 & 3.475 & 3.415 & 4.117 & 4.900 & 5.300 & 0.245 & \begin{tabular}{|l|l|} 
& 0.327 \\
\end{tabular} & \begin{tabular}{|l}
0.318 \\
\end{tabular} & 0.393 & 0.526 & 0.716 & \begin{tabular}{|l|l} 
\\
\end{tabular} \\
\hline
\end{tabular}

2011), whereas in Lviv region it grew to $6.77 \%$ (against 5,23\%). In view of the above, the overall resource efficiency of the Ukrainian industry could be increased given the continuingly growing (from 2014 and on) capital productivity and labor productivity. Yet, if measured by the latter indicator, it was thrice lower than in Poland.

The economic effectiveness of the industry is measured by operating profitability, profitability of turnover, and return on assets. In 2016-2017, the operating profitability in the Ukrainian industry grew, after its considerable decrease in four previous years. In 2017, its average level reached $6.8 \%$, which is 1.45 times higher than in 2011 (see Table 7, the author's calculations by use of data from $[9 ; 13 ; 19$; $20]$ and Chief Statistics Departments in Ukrainian regions). The operational (or main) activity in the industry became profitable in 22 regions (against 10 in 2014).

Profitability of turnover and return on assets in the domestic industry were below zero in 2014 and the following years on account of loss-making result from the normal operations before tax. In 2017, the domestic industry gained the profit worth 87461.7 million UAH (against 7569.6 million UAH in the previous year). This triggered growth in profitability of turnover and return on assets across the industry, which was nearly twice higher than in 2012. Still, the financial result from the normal operations before tax was below zero in 9 regions (against 11 in 2016). In particular, the loss-making of the industry aggravated in Donetsk, Zhytomyr, and Luhansk regions.

In 2017, the highest cost-effectiveness in the industry was recorded for Dnipropetrovsk and Zaporizhzhia regions, which could occur due to the considerable growth in all the three profitability indicators to maximal level among the Ukrainian regions. This growth resulted from the financial result from the normal operations before tax, increased by 3.3 times in Dnipropetrovsk region and 1.7 times in Zaporizhzhia region. A high cost-effectiveness in the industry was also recorded in 2017 for Vinnytsia, Poltava, and Cherkasy regions.

Kharkiv region needs a separate mention because of the continuing profit-making of its industry throughout 2011-2017, in contrast with the other regions. While the financial result from the normal operations in the industry before tax had been falling 


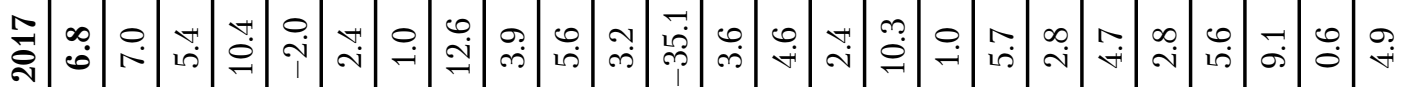

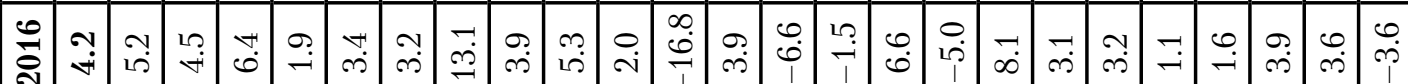

莺

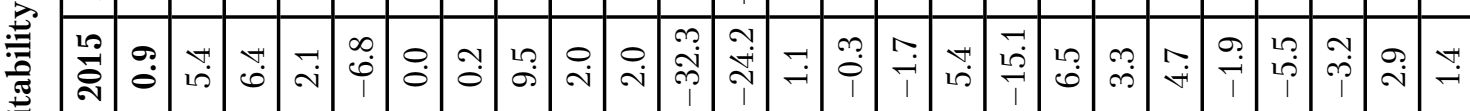

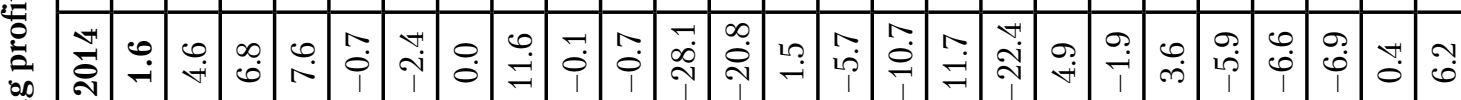

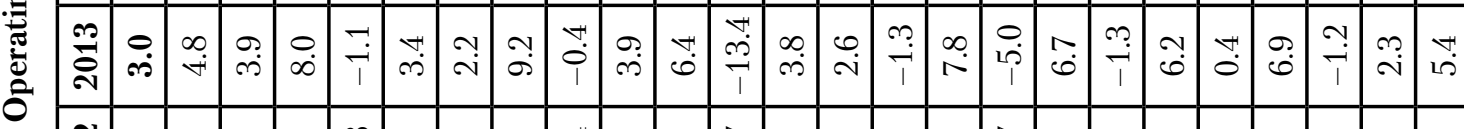

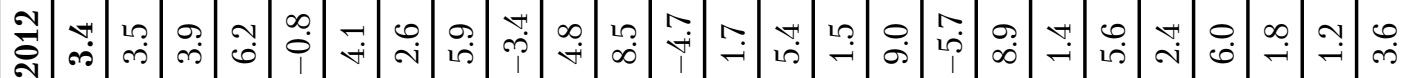

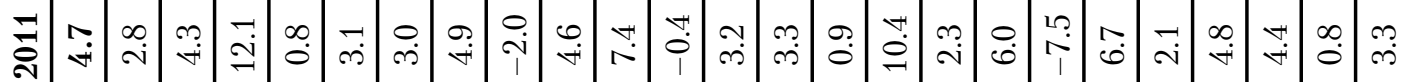

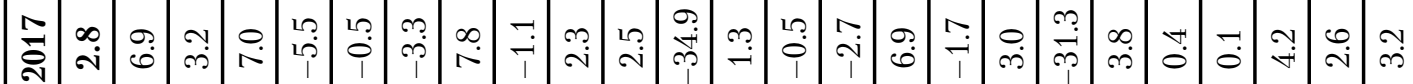

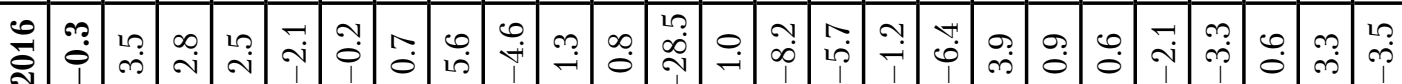

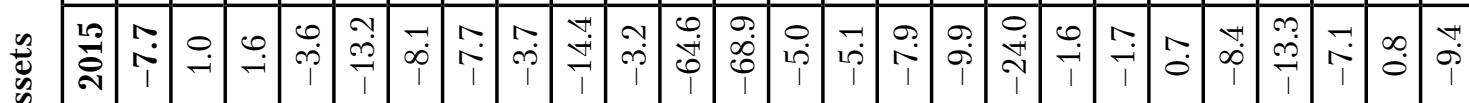

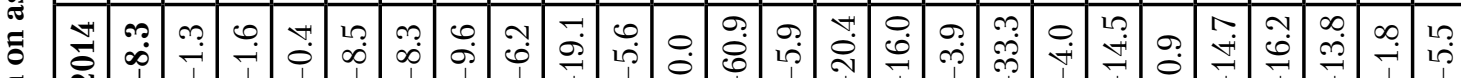

ह

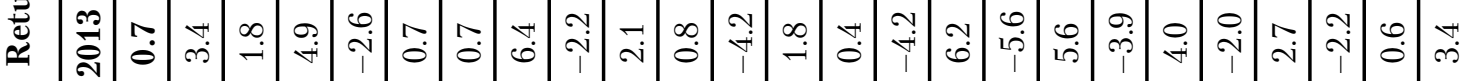

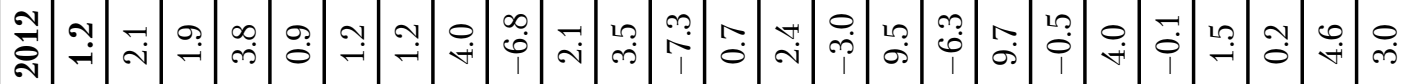

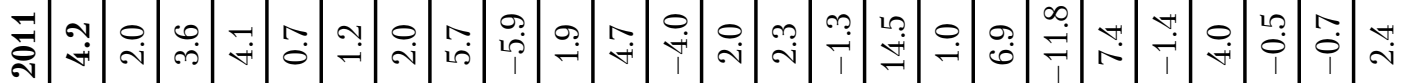

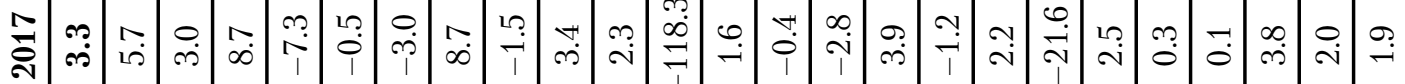

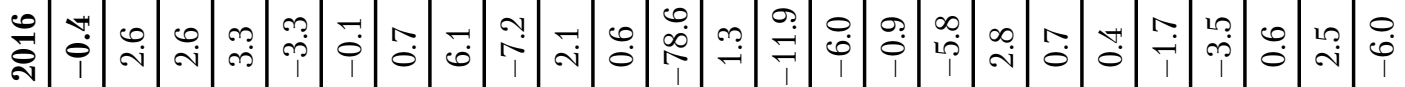

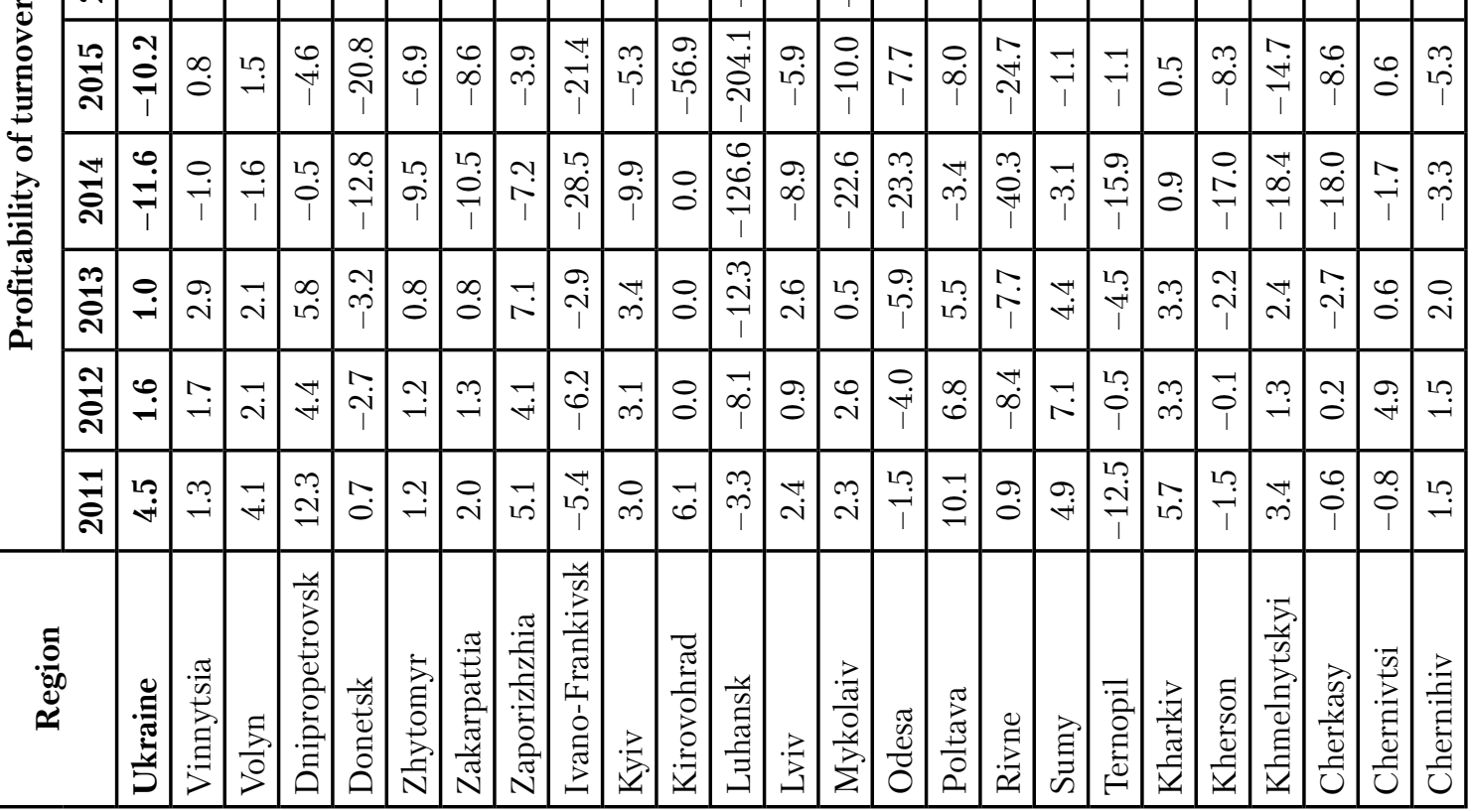


in 2014-2016, it could be increased by 7.4 times in 2017. It should also be noted that absolute positive values of all the profitability indicators in Kirovohrad regions could be increased after their plummeting in 2015.

Conclusions and recommendations. The overall industry performance enhanced in Ukraine in 2017 compared with the previous years. However, the following package of organizational-economic and financial arrangements should be implemented, in order to stop the chronic negative tendencies in the domestic industry (first of all, the degrading structure of assets and the plummeting innovation activity, in particular the shrinking share of innovative products in the total sales of industrial products, etc.), to assure the continuing increase in capital productivity, labor productivity, profitability of industrial entities, to increase the industry's share in the total exports, to increase the industrial investment:

- enhance the innovation activity in every region (stimulate the development of high tech industries);
- promote FDI (expand the access of domestic industrial entities to FDI and enhance the foreign investor's awareness of potential areas for FDI);

- increase the export capacities if necessary (stimulate export activities of enterprises, diversify the commodity structure of domestic exports, balance the commodity structure of exports by trading partners of Ukraine).

A comprehensive solution for the problems related with operation and development of the Ukrainian industry calls for structural modernization of the industry, intended to increase the share of high tech economic activities in the domestic output and exports, to meet the domestic market demand for home-made products and enhance the efficiency of the domestic production. This study of the author will be followed by search for effective models for structural transformation of the Ukrainian economy (its regional level in particular) within the framework of the European platform for smart specialization of the industry. In particular, it is interesting to utilize panel data and to analyze what the variables studied have the most influence/

\section{References}

1. Valovyi vnutrishnii produkt vyrobnychym metodom ta valova dodana vartist za vydamy ekonomichnoi diialnosti [Gross domestic product by production method and gross value added by type of economic activity]. (2017). wrere.ukrstat.gov.ua. Retrieved from: http://www.ukrstat.gov.ua/operativ/operativ2008/vvp/vvp_ric/ vtr_u.htm [in Ukrainian].

2. Zaynyate naselennya za vydamy ekonomichnoi diialnosti ta rehionamy [Employed population by type of economic activity and regions]. (2017). www.ukrstat.gov.ua. Retrieved from https://ukrstat.org/uk/ operativ/operativ2013/rp/zn_ed_reg/zn_ed_reg_u/zn_ed_reg_2017k_u.htm [in Ukrainian].

3. Natsionalni rakhunky. Richni natsionalni rakhunky. Ahrehaty natsionalnykh rakhunkiv za haluziamy [National Accounts / Annual National Accounts / Aggregates of National Accounts sectoral income]. (2017). wrere.ec.europa.eu. Retrieved from http://appsso.eurostat.ec.europa.eu/nui/show.do?dataset=nama_10_ a64\&lang $=\mathrm{e}$

4. Amosha, O. I., Bulieiev, I. P., \& Zaloznova, Yu. S. (Eds.) (2017). Promyslovist' Ukrainy 2014-2016: nevykorystani mozhlyvosti, shliakhy vidnovlennia, modernizatsii ta suchasnoi rozbudovy [Industry of Ukraine 2014-2016: unused opportunities, ways of restoration, modernization and modern development]. Kyiv: Institute of industrial economics of the NAS of Ukraine. Retrieved from http://iie.org.ua/wp-content/uploads/2017/04/ Promislovist-Ukrayini_2017_16_05.pdf [in Ukrainian]

5. Polovian, O. V., Zanizdra, M. Yu., Chekina, V. D., et. al. (2016). Natsionalna model neoindustrialnoho rozvytku [National model of neoindustrial development]. Vyshnevskyi, V. P., Zbarazka, L. O. (Eds.). Kyiv: Institute of industrial economics of the NAS of Ukraine. Retrived from http://iep.com.ua/Vishnevskiy_ Zbarazska Zanizdra Chekina 2016.pdf [in Ukrainian].

6. Vyshnevskyi, V. P., \& Kniazev, S. I. (2017). Smart-promyslovist: perspektyvy i problemy [Smart industry: prospects and challenges]. Ekonomika Ukrainy - Economy of Ukraine, 7, 22-37 [in Ukrainian].

7. Heyets, V. M., \& Ostashko, T. O. (Eds.) (2016). Implementatsiia Uhody pro asotsiatsiiu mizh Ukrainoiu ta YeS: ekonomichni vyklyky ta novi mozhlyvosti [The Implementation of the Agreement about Association between Ukraine and the EU: Economic Challenges and Opportunities]. Kyiv: SO "Institute for Economics and Forecasting of the NAS of Ukraine" [in Ukrainian].

8. Obsiah realizovanoi produktsii (robit, posluh) pidpryiemstv za vydamy ekonomichnoi diialnosti [Volume of sold products (works, services) by type of economic activity]. (2017). wrero.ukrstat.gov.ua. Retrieved from http://ukrstat.gov.ua/operativ/operativ2013/fin/kp_ed/kp_ed_u/orp_ed_u_2017.htm [inUkrainian].

9. Obsiah realizovanoi promyslovoi produktsii za vydamy diialnosti [Volume of industrial products sold by type of activity]. (2017). wrew.ukrstat.goz.ua. Retrieved from http://www.ukrstat.gov.ua/operativ/ operativ2013/pr/orp_rik/orp_rik_u.htm [in Ukrainian]. 
10. Indeksy promyslovoi produktsii v Ukraini [Indices of industrial production in Ukraine]. (2017). wrew. ukrstat.goz.ua. Retrieved from: http://www.ukrstat.gov.ua/operativ/operativ2008/vvp/vvp_ric/vtr_u.htm [in Ukrainian].

11. Indeksy tsin vyrobnykiv promyslovoi produktsii u 2017 rotsi [Industrial producer price indices in 2017]. (2017). wwwe.ukrstat.gov.ua. Retrieved from: http://www.ukrstat.gov.ua/operativ/operativ2017/ct/ icv/icv_u/icv_vp17_u.htm [in Ukrainian].

12. Tovarna struktura zovnishnoi torhivli Ukrainy [Commodity structure of foreign trade of Ukraine]. (2017). wөwø.ukrstat.goz.ua. Retrieved from http://www.ukrstat.gov.ua/operativ/operativ2017/zd/tsztt/ tsztt_u/tsztt1217_u.htm [in Ukrainian].

13. Pokaznyky balansu velykykh ta serednikh pidpryiemstv za vydamy ekonomichnoi diialnosti [Indicators of balance of large and medium enterprises by types of economic activity]. (2017). wrore.ukrstat.gov.ua. Retrieved from http://www.ukrstat.gov.ua/operativ/operativ2017/fin/sbp/sbp_u/sbp_12_17_u.htm [in Ukrainian].

14. Natsionalni rakhunky [National Accounts]. (2017). Official website of the State Statistics Service of Poland. Retrieved from www.stat.gov.pl [in Polish].

15. Kapitalni investytsii za vydamy promyslovoi diialnosti [Capital investment by type of industrial activity]. (2017). wwro.ukrstat.gov.ua. Retrieved from http://www.ukrstat.gov.ua/operativ/operativ2017/ibd/ iki_pr/iki_pr_u/kipr_17_u.htm [in Ukrainian].

16. Investytsiyi zovnishn'oekonomichnoyi diyal'nosti Ukrayiny u 2016 rotsi. Ekspres-vypusk № 100/0/03.5вн-17 [Investments of Ukraine's Foreign Economic Activity. 2016: Express-release № 100/0/03.5in-17]. (2017, February 28). State Statistics Service of Ukraine. Retrieved from http://www. ukrstat.gov.ua/express/ expr2017/02/35pdf.zip [in Ukrainian].

17. Vprovadzhennia innovatsii na promyslovykh pidpryiemstvakh. 2017: stat. zb. [Implementation of innovations at industrial enterprises. 2017: Statistical Yearbook]. (2017). State Statistics Service of Ukraine. Retrieved from https://ukrstat.org/uk/druk/publicat/kat_u/2018/zb/09/zb_nauka_2017.pdf [in Ukrainian].

18. Innovatsiina aktyvnist [Innovative activity]. (2017). wrere.ukrstat.org. Retrieved from https://ukrstat. org/uk/druk/publicat/kat_u/publnauka_u.htm [in Ukrainian].

19. Rentabelnist' operatsiinoi diialnosti pidpryiemstv za vydamy promyslovoi diialnosti [Profitability of operating activity of enterprises by types of industrial activity]. (2017). wrero.ukrstat.gov.ua. Retrieved from http://www.ukrstat.gov.ua/operativ/operativ2017/fin/rodp/rodp_pr/rodp_pr_u/rodp_pr_1217_u.htm [in Ukrainian].

20. Finansovi rezultaty pidpryiemstv do opodatkuvannya za vydamy promyslovoi diialnosti [Financial results of enterprises before taxation by types of industrial activity]. (2017). wrow.ukrstat.goz.ua. Retrieved from http://www.ukrstat.gov.ua/operativ/operativ2017/fin/fin_rez/fr_ed/fr_ed_u/fr_ed_1217_u.htm [in Ukrainian].

\section{C. О. Іщук,}

доктор економічних. наук, професор,

завідувач відділу проблем реального сектора економіки регіонів,

Державна установа "Інститут регіональних досліджень імені М. І. Долішнього

НАН України",

E-mail: iso.ird@ukr.net

ResearcherID: G-6417-2019,

ORCID: https://orcid.org/0000-0002-3698-9039

\section{Ключові тренди розвитку промислового сектору регіонів України}

Поглиблення процесів євроінтеграції актуалізувало необхідність підвищення конкурентоспроможності продукції вітчизняних товаровиробників до рівня держав-членів ЄС. Вирішення цього завдання неможливе без структурної модернізації української промисловості. Своєю чергою, вибір напрямів та механізмів практичної реалізації нової державної промислової політики в Україні (зокрема, на регіональному рівні) має грунтуватися на результатах відповідних аналітичних оцінок.

Метою статті є визначення ключових трендів розвитку промисловості України на підставі оцінювання динаміки значень показників, які системно характеризують рівень функціонування промислового сектору національної економіки у регіональному розрізі.

Результати аналізу виявили, що промисловість залишається провідним видом економічної діяльності в Україні з часткою 34,1\% в обсязі реалізованої продукції (товарів, послуг) у 2017 р. У тому році промисловий сектор національної економіки суттєво наростив виробничу, експортну й інвестиційну активність, а також досяг вищого рівня ефективності, зокрема ресурсної (фондовіддачі та продуктивності 
праці) і економічної (рентабельності операційної діяльності, рентабельності обороту та рентабельності активів). Водночас відбулося подальше зниження рівня інноваційної активності промислових підприємств та їх капіталізації. Певною мірою це пояснюється сповільненням динаміки інвестиційних процесів - темпи приросту капітальних інвестицій у промисловість скоротилися на 18,4в. п.

Для протидії усталеним негативним тенденціям у розвитку промисловості (передусім погіршення структури активів і зниження інноваційної активності, зокрема скорочення частки інноваційної продукції в загальному обсязі реалізованої промислової продукції та ін.), а також для подальшого зростання прибутковості суб'єктів промислової діяльності та збільшення частки промисловості у товарному експорті необхідна реалізація комплексу організаційно-економічних та фінансових механізмів за такими напрямами: стимулювання рівня інноваційної активності; активізація залучення прямих іноземних інвестицій; нарощення експортного потенціалу.

Ключові слова: промисловість, виробництво, експорт, активи, інвестиції, інновації, ефективність, розвиток.

Bibliographic description for quoting:

Ishchuk, S. O. (2019). Core Trends in the Development of the Industrial Sector in the Ukrainian Regions. Statystyka Ukrainy - Statistics of Ukraine, 1, 78-90 [in English]. Doi: 10.31767/su. 1(84)2019.01.09.

Бібліографічний опис для цитування:

Іщук С. О. Ключові тренди розвитку промислового сектору регіонів України (публікується англійською мовою) // Статистика України. 2019. № 1. С. 78-90. Doi: 10.31767/su. 1(84)2019.01.09. 